\title{
A Study of Gary Snyder's Idea of Sacrament
}

\author{
Feng Xinlan* \\ College of Foreign Languages, Hunan University, Changsha, China \\ *Corresponding Author: Feng Xinlan, College of Foreign Languages, Hunan University, Changsha, \\ China
}

\begin{abstract}
Gary Snyder enjoys a great reputation in contemporary America as a poet, essayist, translator as well as environmentalist. He proposes an extraordinary idea about the sacrament in his well-known The Practice of the Wild. This paper attempts to interpret Snyder's understanding of sacrament from three dimensions, namely, its background, characteristics, and contemporary value. It is hoped that this paper can provide a new path to apprehend Snyder's ecological views.
\end{abstract}

Keywords: Snyder; sacrament; grace; environment.

\section{INTRODUCTION}

The English word "sacrament", originally derived from Latin word sacramentum and later Old French sacrement, is used as "the common name for certain solemn ceremonies or religious acts belonging to the institutions of the Christian church". To be specific, it indicates "the Lord's Super, Eucharist or Holy Communion". But, as a matter of fact, in the first century and even in the fifth century, "what we call sacraments were not set sharply apart from other aspects of the Christian revelation" (Nock, 194). Afterward, having been possibly influenced by Judaism pattern and factors within the Christian community itself, Christians began to recognize that "the words which Jesus was believed to have uttered over Bread and Cup brought them into an intimate connection with his sacrificial death" (197), and through bread and wine, they expressed their sense of gratitude to God for what he has sacrificed. Then, in the long run, this blessing or thanksgiving of Christians gained popularity. Today, the sacraments are efficacious signs of grace endowed by the Christ in the name of God. Being viewed as a religious ritual and special ceremony, the rite of the sacrament can only be performed with bread and wine, which is prefigured as Christ's body and blood. The adherents of Christianity who celebrate the sacrament should be grateful to Christ, which is the inherent implication of this rite.

Being brought up in a Christian-dominated northwestern America, Snyder is in no way unfamiliar with the idea of the sacrament. He expresses his personal understanding of sacrament in his prose Survival and Sacrament that "Eating is a sacrament. The grace we say clears our hearts and guides the children and welcomes the guest, all at the same time" (Snyder, 197). He regards every meal people have as a sacrament that deprives others of life. Hence, people should be thankful and pray. This unique point of view shares some similarities with the Christian connotation of gratitude. Furthermore, he suggests that grace should become the credo to cultivate our conditioned mind, educate our immature children and welcome our guests. Taking the ninth chapter Survival and Sacrament as an example, this paper focuses on analyzing the formation of Snyder's idea of the sacrament and its significance in addressing the increasing ecological crises in modern society. This paper contends that Snyder's idea of the sacrament aims to remind people of their proper place in the food chain and to protect the equilibrium and diversity of the ecosystem.

\section{From SaCrament to Grace}

As is documented in records, over the centuries, sacrament plays a vital role in Christian society. Snyder, having investigated ecological thoughts for years, grasped the essence of the sacrament in Christianity and put it into practice. Along with the sacrament, grace has been cited in Christian scriptures, as well; while it echoed the sacramental meaning, that is, its thankfulness to God. With our respect to grace in Buddhism, it also provided Snyder with an avenue to form a unique idea of the sacrament. 
Grace, in general, means "a short prayer of thanks said before or after a meal". As Michael Pollan said, "Many food cultures, particularly those at less of a remove from the land than ours, have rituals to encourage this sort of eating, such as offering a blessing over the food or saying grace before the meal" (Pollan, 196). It seems to be of no differences among religions. However, Buddhism grace shapes a distinctive meaning. For the Zen ritual practice of eating, apart from the regular meal chants of grace, it is emphasized that "Cooks cooking, servers serving, eaters eating--each activity depending on the others.....Traditionally, Zen ritual is a training ground for intensive practice in giving the small ego-bound" (Kaza, 46). It suggests that Buddhism grace reminds Buddhists of the interdependence among activities. Concerning food, this particular item, as is chanted by Barbara O'Brien, "let us reflect on our own work and the effort of those who brought us this food". It is the grace that is reflected from the perspective of Buddhism, an embodiment of observing the intimacy of all beings.

Snyder, a Zen Buddhist, "in the period of Snyder's self-cultivation, he produces a certain degree of understanding and thinking on the core philosophy of Buddhism by reading Buddhist scriptures and the works of Buddhist scholars as well as sitting in meditation" (Luo, 152). Having being piloted by Buddhist thoughts, Snyder "advocates the love and care between creatures and non-living creatures in the void as well as the compassion of Amitabha Buddha" (155). Particularly, given the context of consumerism, Snyder turned his concern to the often said food chain, that is, the mutual relationship between different kinds of species. At the same time, with the "sacrament" derived from the Christian civilization that emphasizes Christ's sacrifice in the sacrament, Snyder blends the two cultures together, injects his own idea based on years of research, and at the end, summarizes the new idea of the sacrament.

\section{Characteristics and Value Orientation}

The word sacrament originates from Christianity. By expanding its notion, Snyder forms a unique ecological value. It is of great significance to understand its characteristics and value orientation.

\subsection{Living with Grace}

Grace is the core value of the sacrament, which entails giving thanks for every meal and vegetable that human beings eat. Gratitude, in Snyder's view, stems from primitive man. "They knew that taking life required gratitude and care" (207). Life and death are a set of both opposite and unified concepts in the primitive society. For people in this surrounding, it becomes an inevitable fact that they sacrifice some other animals to secure their own survival. In the meantime, the dead self-body becomes the nutrients of other things to maintain life, as well. The interconnection between different levels of species presents a dynamic balance. Since the survival of each species is premised on the sacrifice of other species, it is a must for humanity to be grateful for the food they intake, which is quite different from the orientation of individual human demand revealed by consumerism.

There are all sorts of ways to express the gratitude, among which is to trace the life of the inanimate food. Through the example of codfish fry, Snyder approaches the "food we eat as someone's body or part of it. In other words, we have to kill other life forms to maintain our life" (Kim, 39). They are once alive in the water, but "will never, and must never, grow to maturity" (197) when they turn out to be food for humans, as Snyder captures in his words. People do not exactly know how many steps it takes to process the living codfish for gaining inanimate fish chunks, but just the image of the fish itself hopping through water is enough to arouse a sense of awe in their mind while they face the codfish fry on the table, because it is the codfish's life that ensures them to continue sustaining themselves. According to Michael Pollan, "The meat industry understands that the more people know about what happens on the kill floor, the less meat they're likely to eat. That's not because slaughter is necessarily inhumane, but because most of us would simply not be reminded of exactly what meat is or what it takes to bring it to our plate" (Pollan, 304). Each species is only one small part of the food chain in the universe. As time goes by, the human body will also decay and become the sacrament of other species. Snyder suggests that the way he usually employs in his family is "Buddhist grace". Obviously, the way of saying grace is not limited and each person can adapt his or her own way to be grateful. The point is that we endow it with the true meaning that should be practically implemented in the daily activity, namely, cherishing food and abandoning consumerism.

The important reason why Snyder speaks of the word "grace" is the ignorance of human beings. Different from the primitive people centuries ago, people living in modern society are not necessary to 
hunt food by themselves. All kinds of commodities in the mall supply a great selection that can satisfy their material needs. "Our distance from the source of our food enables us to be superficially more comfortable, and distinctly more ignorant" (197). While most people have forgotten that they are an integral part of the natural food chain. Kim Won-Chung also explains that "because most foods are processed and beautifully wrapped, it is not easy for consumers to recognize that many foods are, in fact, the remnants of a death of an animal" (40). Moreover, a prominent American essayist and environmental activist, Wendell Berry, explored the true pleasure of eating and wrote that "Eating with the fullest pleasure-pleasure, that is, that does not depend on ignorance-is perhaps the profoundest enactment of our connection with the world. In this pleasure, we experience and celebrate our dependence and our gratitude, for we are living from mystery, from creatures we did not make and powers we cannot comprehend" (Berry, 152). With their alike attention on human's ignorance and connection with the outside, Snyder illuminates his ecological idea of the sacrament for urging people to be well aware of this issue and participate in change.

\subsection{Raising Environmental Awareness}

The other characteristic of the sacrament is to increase environmental awareness. In other words, people should have this recognition that there is a limited capacity of the earth environment. As human beings have multiplied on a large scale, the natural environment where people live and attain the resource has witnessed a dramatic change in the past dozens of years. For instance, vast tracts of tropical rainforest have been cut down for grazing or logging, with the ultimate aim of providing goods for customers. It's common to see that the natural environment is ruined due to one's own desires, which could be exemplified by the circumstances in Snyder's Survival and Sacrament. It is pointed out that about half of the 10 to 30 million species live in the rainforest, but "About half of those forests, in Asia, Africa, and South America, are already gone" (188). As a matter of fact, globally, "according to statistics, since the establishment of the capitalist mode of production, due to the accelerated speed of biological extinction, the natural ecosystem has suffered the most severe period since the disappearing of dinosaurs 65 million years ago" (Cao, 184).

As far as some people are concerned, acquiring raw materials from nature is only a one-way road. But, it is, actually, a two-way road and people have this need to raise environmental awareness. Nevertheless, this awareness in respect to its true sense should go back to "the culture of the wilderness." Snyder asserts that "on the mythical plane this is the source of the worldwide hero narratives. On the spiritual plane it requires embracing the other as oneself and stepping across the line" (192). Having taken the wilderness as its foundation, human beings are inseparable from the natural environment, but they gradually move away from the wilderness in the subsequent development. In fact, human beings should ultimately integrate themselves with the wilderness, just as people are willing to defend their homeland. In the wilderness family, the relationship between human beings and other species should become more intimate. More importantly, it will not manifest as mutual killing between different levels of species, but maintain a dynamic balance from the biological point of view. "We used to think of wilderness as an integrated part of the functional value, neglecting or disregarding the intrinsic value of the whole kingdom of life and the unique way in which they lived and produced" (Ye, 8). Today, it is essential that people enhance their comprehension of wilderness culture and recognize that human beings are closely related to the natural environment. What's more, it is important to pay attention to the nuance of figuring out the sameness between human beings and the natural environment via the food they eat every day, rather than fight against the natural environment for their self-demand.

\section{CONTEMPorary Social VAlue}

At the micro level, the idea of sacrament advocated by Snyder is based on the personal lives of human beings, highly normative and instructive for people's behaviors. At the macro level, this unique ecological concept also yields momentous value in contemporary society.

\subsection{Leading Consumption Trend}

The Chinese nation has pursued the traditional virtue of thrift since ancient times. With the rise of material civilization, consumerism has dominated society. At this time, the idea of the sacrament acts as an appropriate medicine to cure the sickness of consumerism. During a period of time, as a typical kind of consumerism went viral, "Humans smashed animals and blood filled the world. However, 
animal species were limited and human desires were endless. This unrestrained madness has destroyed the biological chain of nature and would eventually drive human to death" (Wang, 140). If the stability of the biological chain is destroyed, the place of human beings in the chain will be in danger, and as a result, it does harm for humanity itself. When it comes to the sacrament idea, it informs people of recognizing that they are positioned at the same level as other species. Hence, they should strive to overcome consumerism and should not slaughter animals for their endless desires that could damage the biological chain.

The idea of the sacrament calls for all walks of life to respect the equal status of life and to be thankful for the meal they intake every single day. It is greatly beneficial to the formation of new consumption in the whole society. Many people often measure the food they exchange in terms of money. On the surface, it is a normal transaction that consumers pay for food and, then, they should be owned by buyers and can be left to be treated with no regard to the source or production. In truth, food possesses both of its "natural attributes" and original vitality. Having deeply realized the natural attributes, Snyder summarizes the idea of the sacrament. When people look at food from the perspective of biological sense and turn their attention to its natural attributes, they will not be so extravagant while consuming food, nor will they kill animals for the sake of greed, but will fundamentally cherish the meal in a pious mood. What's more important is that the idea of the sacrament can not only be applied to the field of food consumption but also permeate into the wide range of consumption. If the trend of civilized consumption is formed, it will be conducive to maintain the ecological balance ultimately.

\subsection{Sounding Environmental Alarm}

As it enters the 21 st century, environmental protection has been a fervent topic in many fields. As early as the last century, environmentalists began to focus their attention on environmental problems, and, in an active way, they put forward the vision of environmental protection and appealed to the government for issuing environmental protection policies. One of them, the well-known ecologist Snyder, claims the idea of the sacrament to sound the alarm of environmental protection. Starting from the source of the ingredients, Snyder makes people realize that human beings' survival is overly dependent on the environment that the "Lung of the Earth" rainforests are extensively felled due to the pasture construction. Secondly, he cites abundant data, implying that about half of the tropical forests no longer exist, which is a great loss for mankind and the entire nature. To protect the environment, Snyder calls on everyone to take actions for saving food and ridding consumerism.

As Snyder says, "the critical argument now within environmental circles is between those who operate from a human-centered resource management mentality and those whose values reflect an awareness of the integrity of the whole of nature" (193). The idea of the sacrament is on the basis of his comprehension upon the integrity of nature. He sees the destruction of the natural environment that is what humankind has neglected, and what humankind need keep a watchful eye on. This idea leads people to concern about three meals and apprehend the interdependence between individual life and natural environment, and furthermore, deepen people's understanding and recognition of environmental protection.

\subsection{Provoking Ecological Thinking}

Ecological thoughts are often passed on through generations by means of a great number of ecoliterature works. John Burroughs' Wake Robin depicts the vivid musical events of birds in the forest and scientific knowledge about birds, guiding humankind to embrace the beauty of birds, especially the beauty of their voices. Rachel Carson' s Silent Spring, "based on a wealth of facts and scientific knowledge, reveals the global damage and serious ecological crisis brought by the abuse of chemicals such as pesticides and herbicides on the natural environment as well as its persistent, irreversible damage to human health" (Zhu, 66). These works stand out in the literature domain attributed to their unique aesthetic and scientific rigor, making indelible contributions to the dissemination of ecological thoughts and culture. Similarly, Snyder expounds the idea of the sacrament in his prose and spreads it to his readers via the form of words. Differently, the idea he conveys is rooted in the average person's three meals a day. It is accessible to everyone and can be truly experienced and practiced in personal life. This is the highlight of his ecological thinking.

In brief, the idea of the sacrament is not only an organic integration of two different cultures but also an innovative move of ecological thoughts, functioning as a compass for plowing through the ecology 
field. Returning to ordinary being, when we give the sacrament enough concern and attention and develop healthy habits in our personal life, then, even if we are neither Christian nor Buddhist, the sound sacrament in our heart will equip us with a more sacred ecological power, as well.

\section{REFERENCES}

[1] Oxford English Dictionary, https://www.oed.com/.

[2] Nock, A. D. "Hellenistic Mysteries and Christian Sacraments". Mnemosyne 3(1952): 177-213.

[3] Snyder, Gary. The Practice of The Wild, Berkeley: Counterpoint Press, 2010.

[4] Pollan, Michael. In Defense of Food: An Eater's Manifesto, New York: Penguin Press, 2008.

[5] The Omnivore's Dilemma, New York: Penguin Press, 2006.

[6] Kaza, Stephanie. "Becoming a Real Person". Buddhist-Christian Studies 20(2000): 45-53.

[7] O'Brien,Barbara. "Buddhist Verses to Chant Before Eating". Learn Religions 2019, https://www. learnreligions.com/giving-thanks-for-our-food-449751.

[8] Luo Jian. "On the Understanding and Usage of Zen Culture by Gary Snyder during the Self-xiuchan Period" (zi xiu chan jie duan jia li si nai de dui chan zong wen hua de li jie yu yun yong). Journal of Xiangtan University(Philosophy and Social Science) 34(2010): 152-157.

[9] Kim, Won-Chung. "Ecological Eating: Gary Snyder's Existential Koan”. 문학과환경 13(2014): 37-58.

[10] Berry, Wendell. What are People for?, San Francisco: North Point Press, 1990.

[11] Cao Shunxian, Wang Guopin. "The Globalization of the Ecological Crisis" (lun sheng tai wei ji quan qiu hua). Ecological Economy 9(2009): 183-187.

[12] Ye Ping. "The Concept of 'Moor' in the Horizon of Eco-philosophy" (sheng tai zhe xue shi ye xia de huang ye). Philosophical Researches 10(2004): 64-69.

[13] Wang Yuechuan. "The Contemporary Value of Ecological Literature and Ecological Criticism" (sheng tai wen xue yu sheng tai pi ping de dang dai jia zhi). Journal of Peking University(Philosophy and Social Science) 46(2009): 130-142.

[14] Zhu Xianming, Yu Dongyun. "Rachel Carson's Ecological Ideas As Seen from her Silent Spring" (cong ji jing de chun tian kan lei qie er ka sen de sheng tai si xiang). Foreign Literature 3(2006): 65-69.

\section{AUTHORS' BIOGRAPHY}

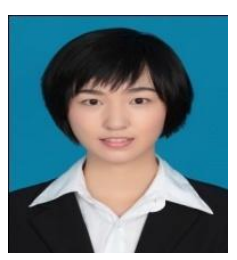

Feng Xinlan is now a graduate student of Hunan University, China. Academic interests are English and American literature as well as translation.

Citation: Feng Xinlan. A Study of Gary Snyder's Idea of Sacrament" International Journal on Studies in English Language and Literature (IJSELL), vol 7, no. 5, 2019, pp. 38-42. doi: http://dx.doi.org/10.20431/ 2347-3134.0705004.

Copyright: () 2019 Authors. This is an open-access article distributed under the terms of the Creative Commons Attribution License, which permits unrestricted use, distribution, and reproduction in any medium, provided the original author and source are credited. 